\title{
Rye: Current state and future trends in research and applications
}

\author{
R. Németh* (1) and S. Tömösközi
}

Research Group of Cereal Science and Food Quality, Department of Applied Biotechnology and Food Science, Faculty of Chemical Technology and Biotechnology, Budapest University of Technology and Economics, Müegyetem rkp. 3., 1111, Budapest, Hungary

\section{REVIEW PAPER}

Received: July 14, 2021 • Accepted: July 16, 2021

Published online: September 29, 2021

(C) 2021 The Author(s)

\section{ABSTRACT}

After wheat, rye is the second most important raw material for bread and bakery products, and it is one of the most excellent sources of dietary fibres and bioactive compounds. Besides, rye is utilised in more and more other food products as well, such as breakfast cereals, porridges, pasta, snack products, etc. Interestingly, its production is decreasing worldwide, probably because of the expansion of other cereals (e.g. triticale), but also the effect of climate change can also play a role therein. However, there is no doubt that scientific research aimed at studying the possible health benefits and the potential of rye in the development of novel food products has intensified over the past decade.

The aim of our paper is to make a comprehensive review of the latest results on the compositional and technological properties of rye that fundamentally influence its utilisation for food purposes. Furthermore, this review aims to identify the current development directions and trends of rye products.

\section{KEYWORDS}

baking quality, novel products, nutritional value, rheological properties, rye

\footnotetext{
*Corresponding author. Tel.: +36(1)4632394. E-mail: nemeth.renata@vbk.bme.hu
} 


\section{INTRODUCTION}

Rye (Secale cereale L.) has been cultivated since ancient times in Europe and is the second most important crop after wheat for production of bread and other bakery products. In botanical classification, rye belongs to the grass family Poaceae, the subfamily Pooideae, and the tribe Triticeae along with other cereals like wheat and barley. Most of the cultivated rye species are members of the genus Secale, and has probably evolved from a perennial grass (Secale montanum) that still grows wild in southern Europe (Arendt and Zannini, 2013; Sapirstein and Bushuk, 2016; Wrigley and Bushuk, 2017). Although rye is now cultivated worldwide, in terms of total production it is a minor cereal. The distribution of rye production differs from that of wheat, due to its demand for cooler growth temperatures and large differences in regional preferences for rye-based products (Poutanen et al., 2014; Wrigley and Bushuk, 2017). Europe provides more than $85 \%$ of the world's rye production (12.8 million tons, 2019), including the leading rye producing countries: Germany, Poland, Russia, Denmark, and Belarus. In the last decade (2009-2019), the world's rye production dropped significantly preceded even by the cultivation of triticale (14 million tons, 2019) (FAO, 2019). At the same time, the increasing research data on rye points out its relevance as an important raw material for healthy foods and its decisive role in developing novel products. Besides, our knowledge on its milling and technological properties are expanding as well, however, these data have been reviewed to a lesser extent yet.

Therefore, our review focuses on the one hand on the nutritionally important chemical composition and current health claims of rye, on the other hand on the most recent results on the techno-functional properties and quality testing of rye and on its potentials for product development.

\section{COMPOSITION AND HEALTH EFFECTS}

The chemical composition of rye shows similarities with other cereals (e.g. wheat, barley, and triticale), however, it can be characterised by higher fibre (especially pentosan) content regarding both the whole grain and endosperm, which is considered as the main nutritional benefit of rye (Shewry et al., 2013; Poutanen et al., 2014; Békés and Wrigley, 2015; Sapirstein and Bushuk, 2016) accompanied with its high content of bioactive compounds (Jonsson et al., 2018).

\subsection{Macro- and micronutrient composition}

Protein content of rye can vary in a wide range (8-15\%) depending mainly on growth conditions (Kučerová, 2009; Sapirstein and Bushuk, 2016; Laidig et al., 2017). However, the higher influence of genotype compared to environmental effect has been also reported (Hansen et al., 2004; Kunkulberga et al., 2017). Albumins are the main proteins of rye, accounting for $29-40 \%$ of the total protein content. Globulins make up $8-11 \%$, while the storage proteins of rye (so called secalins), the prolamins and glutelins, make up $17-19 \%$ and $9-15 \%$ of the total protein content, respectively. About $21-30 \%$ of the proteins are unextractable based on Osborne fractionation. The amino acid composition of rye proteins is slightly better than that of wheat due to its higher lysine content, but it is limiting in tryptophan and isoleucine (Chen and Bushuk, 1970; Hulse and Laing, 1974; Békés and Wrigley, 2015; Redant et al., 2017). 
The most evident carbohydrate component of rye is starch, similarly to other cereals. The starch content of the rye grain ranges from 55 to $65 \%$, which is little lower than that of wheat (63-72\%) and higher than that of barley (50-64\%) (Poutanen et al., 2014; Sapirstein and Bushuk, 2016). Rye starches, like those of wheat and barley, are composed of large (A-type, 6090\%) and small (B-type, 10-40\%) granules with diameters of $23-40 \mu \mathrm{m}$ and less than $10 \mu \mathrm{m}$, respectively. Amylose content of rye starches varies between 22 and $26 \%$ in general (Stoddard, 1999; Verwimp et al., 2004; Gomand et al., 2011; Grossmann and Koehler, 2016), however, higher value (30.1\%) has also been reported (Klassen and Hill, 1971). The lipid content of rye is similar to that of wheat (2-3\%) (Sapirstein and Bushuk, 2016), also fatty acid composition shows similarities having linoleic acid (18.9-59.3\%) as a major component (Kan, 2015; Bağc1 et al., 2019).

Mineral and vitamin composition of rye resembles to that of other cereals (Table 1). Cereals are considered as good sources of phosphorus, potassium, and magnesium, as well as B vitamins (thiamin, riboflavin, niacin, pantothenic acid, and pyridoxine) and folate. Compared to other cereals, rye has higher iron, zinc, manganese, and copper contents, generally. Furthermore, rye is good source of $\alpha$-tocopherol similarly to wheat, however, oat can be characterised by the highest vitamin E content (Frølich et al., 2013; Sapirstein and Bushuk, 2016; Bağc1 et al., 2019).

\subsection{Rye: valuable source of dietary fibres and bioactive compounds}

Non-starch polysaccharides (NSP) along with lignin make up the dietary fibre content of rye, which is the highest among the cereals (Table 2) ranging between 15 and 25\% (Nyström et al., 2008; Shewry et al., 2013; Poutanen et al., 2014; Sapirstein and Bushuk, 2016). The most important NSP component of rye is arabinoxylan (AX), which is a cell wall polysaccharide consisting of a backbone of $(1 \rightarrow 4)-\beta$-D-xylo-pyranosyl residues mainly substituted with $\alpha$-Larabino-furanosyl residues to varying degrees at the O-2 position, the O-3 position, or both (Knudsen and Lærke, 2010). Ferulic acid is additionally attached to arabinosyl units of the polymer chain via ester linkages (Bender et al., 2017). Total and extractable AX content of the rye grain ranges from 7.5 to $11.5 \%$ and from 2.1 to $4.0 \%$, respectively (Hansen et al., 2004; Andersson et al., 2009). In the HEALTHGRAIN variety screen study, total AX content of the bran and flour fractions was $12.1-14.8 \%$ and 3.1-4.3\%, respectively (Nyström et al., 2008; Shewry et al., 2013). Rye also contains 1.5-3\% $\beta$-glucan (Andersson et al., 2009; Poutanen et al., 2014) and 3.6-6.6\% fructan (Karppinen et al., 2003; Andersson et al., 2009; Ispiryan et al., 2020).

Rye grain is also rich in various phytochemicals such as phenolic acids $\left(491-1,082 \mathrm{mg} \mathrm{kg}^{-1}\right)$, tocols (44-67 mg kg$\left.{ }^{-1}\right)$, phytosterols (707-1,420 $\mathrm{mg} \mathrm{kg}^{-1}$ ), lignans (25-67 mg kg-1), and alkylresorcinols (663-1,231 $\mathrm{mg} \mathrm{kg}^{-1}$ ), and besides, several other bioactive compounds have also been identified in rye such as flavonoids $\left(46 \mathrm{mg} \mathrm{kg}^{-1}\right)$, anthocyanins $\left(3.6 \mathrm{mg} \mathrm{kg}^{-1}\right)$, anthocyanidins (1.8 $\mathrm{mg} \mathrm{kg}^{-1}$ ), benzoxazinoids (75-95 $\mathrm{mg} \mathrm{kg}^{-1}$ ), and phenolamides (Nyström et al., 2008; Andersson et al., 2014; Pihlava et al., 2018; Kulichová et al., 2019).

\subsection{Health benefits and possible adverse effects of rye consumption}

Currently there is one health claim authorised by EU according to the positive scientific opinion issued by the European Food Safety Authority (EFSA) Panel on Dietetic Products Nutrition and Allergies (NDA) (2014). This claim states the beneficial physiological effects of rye fibre on bowel function, provided that sufficient amount is consumed. 
Table 1. Mineral and vitamin contents of rye compared to other cereals

\begin{tabular}{|c|c|c|c|c|c|}
\hline & Rye & Wheat & Barley & Triticale & Oat \\
\hline \multicolumn{6}{|c|}{ Minerals $\left(m g \mathrm{~kg}^{-1}\right)$} \\
\hline $\mathrm{P}$ & $1,806-4,220$ & $1,500-5,400$ & $2,700-3,600$ & $3,210-3,850$ & $4,510-5,020$ \\
\hline $\mathrm{K}$ & $3,480-6,148$ & $2,900-6,200$ & $3,190-4,400$ & $4,660-4,700$ & $3,890-4,250$ \\
\hline $\mathrm{Ca}$ & $157-1,447$ & $370-1,220$ & $400-2,700$ & $350-400$ & $500-590$ \\
\hline $\mathrm{Mg}$ & $920-1,602$ & $900-2,900$ & $660-1,800$ & $1,100-1,530$ & $1,220-1,580$ \\
\hline $\mathrm{Fe}$ & $27-129$ & $28-42$ & $30-76$ & $26-37$ & $43-47$ \\
\hline $\mathrm{Zn}$ & $21-52$ & $19-32$ & $14-23$ & $25-27$ & $29-37$ \\
\hline $\mathrm{Mn}$ & $20-75$ & $5-49$ & $13-22$ & 26 & $41-45$ \\
\hline $\mathrm{Cu}$ & $3-13$ & $4-7$ & $3-4$ & 3 & $3-5$ \\
\hline \multicolumn{6}{|c|}{ Vitamins ( $m g \mathrm{~kg}^{-1}$ ) } \\
\hline Thiamin & $4.0-4.6$ & $5.0-12$ & $2.0-2.6$ & $3.8-9.8$ & $5.0-8.0$ \\
\hline Riboflavin & $1.8-1.9$ & $1.0-3.1$ & $0.9-1.0$ & 1.3 & $1.0-1.4$ \\
\hline Niacin & $12-15$ & $41-64$ & $45-50$ & 29 & $9.6-16$ \\
\hline Pantothenic acid & 10 & $7.7-9.1$ & 3.5 & $6.5-8.8$ & 13.4 \\
\hline Pyridoxine & $3.0-3.4$ & $3.0-4.7$ & $3.0-3.2$ & 4.0 & $2.0-2.4$ \\
\hline Folate & $0.48-0.52$ & $0.35-0.56$ & $0.19-0.25$ & 0.7 & $0.45-0.60$ \\
\hline$\alpha$-Tocopherol & $10-12$ & $5-12$ & $3.4-4.0$ & 9.0 & $8.0-18$ \\
\hline References & \multicolumn{5}{|c|}{$\begin{array}{l}\text { Michela and Lorenz (1976); Welch (2011); Frølich et al. (2013); Sapirstein and } \\
\text { Bushuk (2016); Zhu (2018); Bağc1 et al. (2019); Bie et al. (2020) }\end{array}$} \\
\hline
\end{tabular}

Table 2. Dietary fibre content and composition of rye grain compared to other cereals (\% in dry matter basis)

\begin{tabular}{lccccc}
\hline & Rye & Wheat & Barley (hulled) & Triticale & Oat (hulled) \\
\hline Total dietary fibre & $15.0-25.0$ & $10.0-17.0$ & $8.0-16.2$ & $7.5-16.0$ & $11.8-19.1$ \\
Soluble dietary fibre & 2.5 & 3.6 & 4.1 & $2.6-3.2$ & $3.5-12.3$ \\
Insoluble dietary fibre & 13.2 & $9.4-12.0$ & 12.1 & $11.4-12.0$ & $6.8-8.3$ \\
Total arabinoxylan & $6.0-11.5$ & $5.6-0.2 .6$ & 5.2 & $4.1-7.5$ & $1.1-2.0$ \\
Water extractable arabinoxylan & $1.05-4.0$ & $0.6-1.0$ & $1.1-1.4$ & $0.21-0.44$ & $0.15-0.18$ \\
Cellulose & 2.9 & $2.4-2.5$ & 1.9 & $1.7-2.5$ & 1.3 \\
$\beta$-glucan & $0.7-3.0$ & $0.5-1.1$ & $3.2-4.6$ & $0.5-2.1$ & $3.9-7.1$ \\
Fructan & $3.6-6.6$ & 1.3 & 1.6 & $1.6-2.9$ & 1.4 \\
Arabinogalactan & $0.9-1.0$ & $0.89-1.09$ & $0.71-0.97$ & $0.14-0.23$ & 0.01 \\
Klason lignin & 1.1 & $0.8-1.9$ & 0.7 & $1.4-3.2$ & $1.4-5.9$ \\
References & Karppinen et al. (2003); Nyström et al. (2008); Andersson et al. (2009); \\
& Göllner et al. (2011); Rakha et al. (2011); Saeed et al. (2011); Doehlert \\
& et al. (2013); Shewry et al. (2008, 2013); Frølich et al. (2013); Knudsen \\
& (2014); Piironen and Lampi (2014); Poutanen et al. (2014); Chibbar \\
& et al. (2016); Fraś et al. (2016); Sapirstein and Bushuk (2016); Aprodu \\
& and Banu (2017); Langó et al. (2017, 2018); Zhu (2018) Biel et al. \\
& (2020); Cetiner et al. (2020); Ispiryan et al. (2020); Liu et al. (2020) \\
\hline
\end{tabular}


Several studies have been focusing on the potential health effects of rye and rye-based products, and the clinical studies and findings until 2018 have been reviewed comprehensively by several authors (Afzal et al., 2013; Arens, 2015; Jonsson et al., 2018).

The main objectives of most clinical trials have been the investigation of the role of rye consumption in the prevention of cardiovascular disease, type 2 diabetes, and certain cancers (mainly colorectal cancer). Furthermore, the impact of rye consumption on gut health, hormone secretions, and blood glucose levels, as well as on LDL cholesterol concentration has also been studied comprehensively. However, there are several studies, which refute the effect of rye product consumption e.g. on blood glucose and insulin level (Leinonen et al., 2000; Juntunen et al., 2002) or on the concentrations of biomarkers of inflammation and cardiovascular disease (Mhd Omar et al., 2020). The main reason of controversial results might be the limitations of clinical trials, such as their high cost and usually small sample size. However, when comparing the results of clinical trials, the characteristics of the investigated dietary fibres and bioactive compounds, the type of the involved food matrices (i.e. white, mixed, or whole grain products, etc.), and the eating habits of the test persons should be also taken into account. In the case of other mentioned health benefits, there is not enough scientific evidence for establishing cause and effect relationships yet.

However, in some individuals, rye consumption might have also adverse effects. Since rye also contain gluten homologous proteins, its consumption is not allowed in case of celiac disease (Malalgoda and Simsek, 2017). Rye based products (especially wholemeal or bran-rich, nonfermented) might contain significant amount of fructan, which is the most prominent FODMAP (fermentable oligosaccharides, disaccharides, monosaccharides, and polyols) component of the grain. It concentrates in the bran fraction $(6.6 \mathrm{~g} / 100 \mathrm{~g})$, but also refined light flours can contain around $3 \mathrm{~g} / 100 \mathrm{~g}$ fructan (Karppinen et al., 2003; Pejcz et al., 2020). FODMAPs that were not digested and absorbed in the small intestine are easily fermentable by enteric microflora, which triggers symptoms of the irritable bowel syndrome (IBS). The IBS affect around 7-21\% of people in the world including gastrointestinal disorders such as chronic recurring flatulence, pain perceptible in the abdomen, and changes in defecation rhythm (Pejcz et al., 2020).

\section{INVESTIGATION OF TECHNO-FUNCTIONAL PROPERTIES}

\subsection{Grain quality and milling properties}

Grain quality assessment for rye is basically similar to that for wheat, however, there are some quality aspects of especially great importance such as grain soundness (lack of sprouting), test weight, and presence of ergot bodies (Wrigley and Bushuk, 2017).

The rye grain milling process is similar to that of wheat, although, some important differences exist between them, such as the shorter tempering period and the application of corrugated rolls instead of smooth rolls for reduction in the case of rye. Rye flour also needs larger sifting surface to avoid clumps. These can be explained by the softer endosperm of rye compared to wheat (Arendt and Zannini, 2013). The extraction rate of rye flour is usually lower than that of wheat, because it is difficult to separate the endosperm from the seed coat, especially in grain with a higher content of non-starch polysaccharides (Warechowska et al., 2019). Rye flours are generally classified on the basis of ash content, and their number varies nation to nation. As an 
example, in Germany, eight flour grades can be distinguished having ash contents ranging from 0.9\% to above 1.8\% (Arendt and Zannini, 2013; Sapirstein and Bushuk, 2016).

\subsection{Technological properties of rye flours}

A broad range of testing methods has been established to predict end-product quality of flours (Tömösközi and Békés, 2016). As in wheat baking performance is influenced to a great extent by its protein (gluten) and starch fractions, specific (rapid) methods are designed to measure protein (or gluten) quantity and quality and starch quality. Similarly to wheat, the end-product quality of rye flours is affected by the storage proteins, starch, and non-starch polysaccharides. However, the carbohydrate fraction as well as $\alpha$-amylase activity play a more important role in formation of functional properties. Therefore, the aim of existing methods is mainly to describe dough making and gel forming properties of these components (Lindhauer, 2014; Laidig et al., 2017).

It should be mentioned that no standardised procedure for laboratorial rye flour production has been developed yet, like in the case of wheat, therefore, the investigated samples can vary greatly in ash content and particle size distribution. Furthermore, in many cases, the type of rye milling products is not clarified in the articles, making the comparison of literature data and drawing general conclusions more difficult.

3.2.1. Dough-forming properties. To measure dough properties, empirical and fundamental rheological methods are usually applied. Based on the results of standard Farinograph and Mixolab measurements, mixing properties of rye doughs made from white (ash content of 0.5$0.7 \%$ ) and from fibre-rich or wholemeal flour (ash content of 1.0-1.8\%) differ greatly from their wheat counterparts, and they can be characterised generally by shorter development time and stability, as well as higher degree of softening (Munteanu et al., 2015; Bucsella et al., 2016; Aprodu and Banu, 2017; Ponomareva et al., 2018).

The functionality of individual rye constituents (proteins, starch, and non-starch polysaccharides) and their interactions on dough properties have been investigated comprehensively in the last ten years. It is generally accepted that rye storage proteins are not able to form as strong viscoelastic network as wheat gluten proteins, which is explained by the basically different protein composition and lower protein content of rye (Meeus et al., 2020). However, increased protein aggregation can be achieved in rye dough (flour type 1,150 ) by using transglutaminase (TG) resulting in a more stable and elastic protein network, referring to the structure building potential of rye proteins (Beck et al., 2011; Grossmann et al., 2016). Based on a fractionationreconstitution study of rye flour (type 1,150 ), it was assumed that especially non-gluten proteins (albumins) might play a role in the functionality of rye proteins (Grossmann and Koehler, 2016).

Starch is the main component of rye grain and flour and has a great impact on rye dough behaviour accompanied with amylase activity. Starch granules of different rye flours can be characterised by a higher level of enzymatic and mechanical damage, as well as higher swelling ability compared to wheat starch resulting a softer, stickier dough (Buksa et al., 2010; Deleu et al., 2020; Sluková et al., 2021).

Among non-starch polysaccharides, pentosans, mainly arabinoxylans (AXs), affect rye dough behaviour to a great extent depending on their solubility, molecular weight, and crosslinking ability. AXs (especially water extractable fractions) are able to form highly viscous 
solutions in water, therefore, they are the main contributor to the high viscosity of rye dough (Buksa et al., 2013; Buksa, 2016). Fundamental rheological studies of reconstituted rye dough showed that water unextractable AXs increase, while water extractable AXs decrease dough elasticity (Grossmann and Koehler, 2016). Other studies reported the possible hindering effect of AXs on protein interactions in rye model dough systems. Based on CLSM (confocal laser scanning microscopy) images it was confirmed that proteins were less dispersed and were surrounded by AX network in rye dough, especially at AX concentrations corresponding to commercial rye flours (5-7.5\%). However, no stretched protein fibrils were detected in rye dough at $0 \% \mathrm{AX}$ addition, which further confirms the weak network formation ability of rye proteins (Döring et al., 2015). The functionality of rye AXs can be investigated by enzymatic treatments. It has been shown that the encapsulation of proteins by AX can be reduced by the addition of xylanase (Grossmann et al., 2016; Döring et al., 2017). The treatment of rye dough by pentosanase enzymes resulted in improved extensibility, which was explained by the fact that hydration capacity of pentosans has been reduced due to hydrolysis, and the water could be absorbed by proteins and other components of the flour (David et al., 2019).

Most recent studies on rye dough liquor air-water interfaces showed that lipids hinder proteins to form strong viscoelastic films (Janssen et al., 2020a), while arabinoxylans strengthen the film, acting presumably as a secondary stabilising layer (Janssen et al., 2020b).

In conclusion, the findings about the role of rye constituents in dough formation are sometimes controversial and not fully understood yet, indicating that further research works are needed in this field.

3.2.2. Pasting and thermomechanical properties. In rye quality testing, investigation of carbohydrate-dependent traits such as swelling, pasting, and retrogradation dominate. Furthermore, rye is susceptible to pre-harvest sprouting, therefore, the measurement of $\alpha$-amylase activity and properties related to it have a great importance as well. The determination of Falling Number or Stirring Number are the most general procedures to determine the amylolytic status of rye grain and flours (Wrigley and Bushuk, 2017), while more information on rye flour functionality can be obtained with viscosymetric methods such as Amylograph (Hansen et al., 2004) or Rapid Visco Analyser tests (Gómez et al., 2009). Since viscous properties highly affect bread properties, amylograph measurements and the determination of falling number are usually applied to predict baking performance (Laidig et al., 2017). However, according to recent studies, these methods seemed to be less sufficient for estimating wholemeal bread properties (Stępniewska et al., 2019) and the baking quality of modern rye cultivars (Lindhauer, 2014). A relatively new testing method, the Mixolab is used for the examination of thermomechanical properties in dough matrices instead of slurry, modelling the conditions during bread baking more accurately (Dubat, 2010).

Viscous properties of white (ash content: $0.5-0.7 \%$ ) and wholegrain rye flours measured by the most common testing methods are summarised and compared to wheat flours in Table 3 .

It is well-known that rye flours can be characterised by lower Falling Number values than wheat flours, due to the weaker sprout resistance and, therefore, higher amylase activity of the grains (Wrigley and Bushuk, 2017). According to literature data, the viscosity of white and wholemeal rye flour pastes is usually lower than that of corresponding wheat flours including peak viscosity, hot paste viscosity, and final viscosity. Regarding thermomechanical properties, 
Table 3. Pasting properties of rye and wheat flours determined by different methods

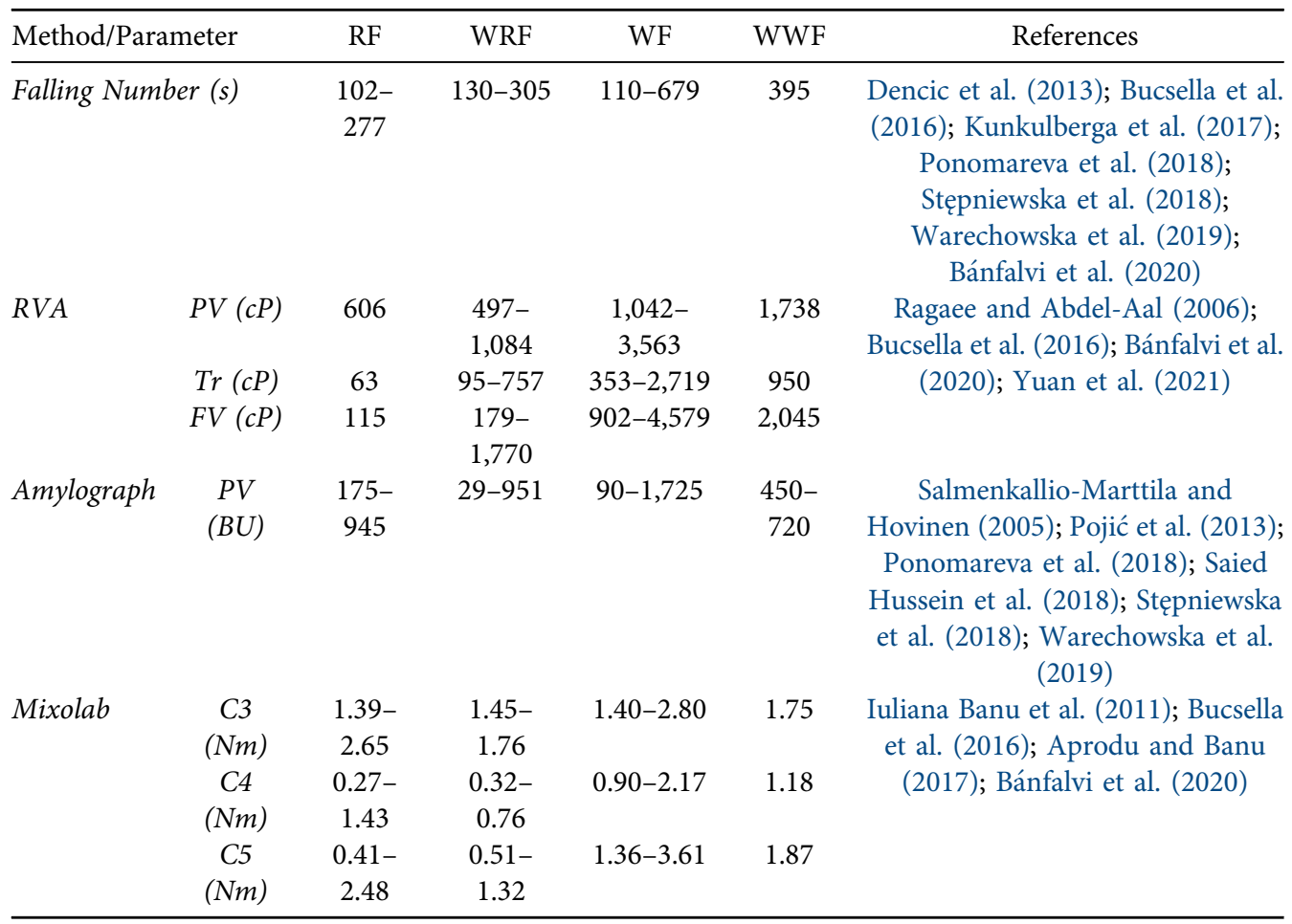

RF: rye flour; WRF: wholemeal rye flour; WF: wheat flour; WWF: wholemeal wheat flour; PV: peak viscosity; Tr: trough; FV: final viscosity.

rye doughs show similar gelatinisation (C3 torque) properties to wheat doughs, but they can be characterised by higher breakdown ( $\mathrm{C} 4$ torque) and lower degree of retrogradation ( $\mathrm{C} 5$ torque).

The differences in pasting behaviour can be explained by several reasons. As mentioned before, rye starch shows a higher level of enzymatic and mechanical damage compared to wheat starch (Sluková et al., 2021). Besides, a comparative study (Gomand et al., 2011) on isolated rye and wheat starches showed that rye starch had higher relative crystallinity, lower gelatinisation and pasting temperatures, lower peak and breakdown viscosities, higher setback, and a lower tendency to retrograde. These can be explained by the structural differences (different chain length distribution profile) of rye and wheat amylopectin and amylose. The slower retrogradation of rye flours can be also related to their pentosan content and composition (Stępniewska et al., 2018). Besides, higher amounts of soluble fibre in white and wholemeal rye flours compared to wheat flours can limit starch swelling and cause higher gelatinisation temperature of rye starch (Aprodu and Banu, 2017).

3.2.3. Baking quality of rye. Bread and other baked products are the main foods produced from rye (Sapirstein and Bushuk, 2016), therefore, the determination of baking quality is similarly important as in the case of wheat. Although baking tests are time-consuming and 
labour-intensive procedures, end-product quality can be determined directly only by these procedures. Rye breads can be very different in shape, colour, flavour, and texture and are also often mixed with wheat flour (Arendt and Zannini, 2013; Sapirstein and Bushuk, 2016). This might be one possible reason why bread making tests for rye are less advanced on the international level compared to wheat bread making, and only a general guidance (ISO, 1985) is available currently. In rye producing countries, there are their own national standard methods for testing baking performance of rye. For example, in Germany, there are different standard protocols (Meißner and AGF, 2016) for performing baking tests specifically from rye flours. There are methods for yeast-leavened bread, sourdough bread, and bread acidified with lactic acid as well as for bread baked with or without baking pan. In Hungary the lactic acid method is used for making test breads from rye (MSZ: 6369/8, 1988). When surveying the literature, the applied methodologies for analysing baking performance of rye flours show great variability (Table 4). What they have in common is that conventional "soft" breads are produced and usually wholemeal rye flours are investigated.

Generally, baking of rye bread differs considerably from that of wheat bread, since rye dough is usually sticky, difficult to handle, and capable of very low gas retention resulting in lowvolume bread with a coarse crumb (Katina et al., 2014; Sapirstein and Bushuk, 2016).

The role of proteins in rye bread quality is less evident yet, although they are important for the typical flavour and taste of rye sourdough bread (Deleu et al., 2020). Based on some studies, however, high protein content is usually less beneficial for breadmaking (Stępniewska et al., 2019).

Starch properties such as amylose content, swelling capacity, and, consequently, solubility and pasting temperature are of high importance in rye bread quality during and after baking (Buksa et al., 2010). A-type starch transforms after baking into hydrated crystalline forms during storage. The relative crystallinity of starch in rye sourdough bread is lower and increases more slowly than in wheat bread (Mihhalevski et al., 2012), which can be traced back to the differences in starch properties discussed in 3.2.2.

Several research works confirmed that rye bread quality (e.g. volume) is highly influenced by the proportion of water extractable to total pentosans. The analysis of industrial high extraction rye flours showed that bread with a higher volume was generally obtained from rye flours characterised by lower protein, pentosans, and water-insoluble pentosans contents and a higher percentage of water-soluble pentosans content (Stępniewska et al., 2019). In another study, rye flours of poor baking quality showed a higher ratio of insoluble-to-soluble non-starch polysaccharides (NSPs) than those of medium or good quality, confirming that composition and structure of NSPs play an important role in final bread quality. The role of water extractable rye arabinoxylans with varying molar mass and molecular characteristics was investigated in model breads prepared from fractionated and reconstituted wholemeal rye flours (Buksa et al., 2016). It was found that the amounts of AXs leading to positive changes were limited, because their excessive addition caused an increase in water content of the dough, and in consequence high adhesiveness of the crumb (or excessive dilution of dough), which led to deterioration of bread quality.

More information can be obtained when the effect of flour constituents is studied together so their relationship can be revealed. Arabinoxylan-protein complexes in model rye bread have been identified, and the highest bread volume was obtained when starch, proteins, and AXs were present together. In this case the AX/protein complexes had the highest molecular weight. It was 
Table 4. Examples of usually applied baking protocols for investigation of baking quality of rye flours

\begin{tabular}{|c|c|c|c|c|c|c|c|}
\hline Raw material & Dough type(s) & Mixing & Resting & Dividing/Shaping & Proofing & Baking & Reference \\
\hline $\begin{array}{l}\text { Rye wholemeal } \\
(1,200 \mathrm{~g})\end{array}$ & $\begin{array}{c}\text { Imitated } \\
\text { sourdough with } \\
\text { lactic acid and } \\
\text { acetic acid }+ \text { dry } \\
\text { yeast }\end{array}$ & $\begin{array}{l}\text { 1. Hand mixer } \\
\text { (1 min }) \\
\text { 2. Hobart mixer } \\
(9 \mathrm{~min})\end{array}$ & $\begin{array}{l}30 \mathrm{~min} \text {, } \\
30^{\circ} \mathrm{C} \\
\text { Further } \\
\text { mixing } \\
(1 \mathrm{~min})\end{array}$ & $\begin{array}{l}\text { Dividing dough } \\
\text { into } 3 \text { pieces } \\
\text { (700 g each) } \\
\text { Uniformly } \\
\text { distributed in } \\
\text { baking pans }\end{array}$ & $\begin{array}{c}37 \mathrm{~min}, 37^{\circ} \mathrm{C} \\
89 \% \mathrm{rh}\end{array}$ & $\begin{array}{l}\text { Preheating: } \\
250^{\circ} \mathrm{C} \\
\text { Steaming: } 20 \mathrm{~s} \\
\text { Baking: } 35 \mathrm{~min} \text {, } \\
200^{\circ} \mathrm{C}\end{array}$ & $\begin{array}{c}\text { (Boskov } \\
\text { Hansen et al., } \\
\text { 2002) }\end{array}$ \\
\hline $\begin{array}{l}\text { Wholemeal rye } \\
\text { flour (792 g) }\end{array}$ & $\begin{array}{l}\text { Yeast/sourdough } \\
\text { with yeast } / \\
\text { sourdough } \\
\text { without yeast }\end{array}$ & n. d. & $\begin{array}{l}30 \mathrm{~min}, \\
30^{\circ} \mathrm{C}, \\
100 \% \mathrm{rh}\end{array}$ & $\begin{array}{l}\text { Dividing into } \\
450 \mathrm{~g} \text { pieces } \\
\text { Moulding by } \\
\text { hand and panning }\end{array}$ & $15 \min , 30^{\circ} \mathrm{C}$ & $60 \mathrm{~min}, 200^{\circ} \mathrm{C}$ & $\begin{array}{l}\text { (Kariluoto } \\
\text { et al., 2004) }\end{array}$ \\
\hline Rye wholemeal & $\begin{array}{l}\text { Yeast } \\
\text { fermentation } \\
\text { (water addition } \\
\text { equivalent to } \\
200 \mathrm{FU} \text { ) }\end{array}$ & Diosna mixer & $\begin{array}{l}90 \mathrm{~min}, \\
37^{\circ} \mathrm{C}\end{array}$ & $\begin{array}{l}\text { Dividing into } \\
\text { pieces containing } \\
100 \mathrm{~g} \text { flour } \\
\text { Moulding and } \\
\text { panning }\end{array}$ & $60 \mathrm{~min}, 37^{\circ} \mathrm{C}$ & $30 \mathrm{~min}, 230^{\circ} \mathrm{C}$ & $\begin{array}{l}\text { (Buksa et al., } \\
\text { 2010) }\end{array}$ \\
\hline $\begin{array}{l}\text { Rye flour type } \\
\quad 1,150(720 \mathrm{~g})\end{array}$ & $\begin{array}{c}\text { Yeast } \\
\text { fermentation }\end{array}$ & $\begin{array}{c}25^{\circ} \mathrm{C} \\
4 \text { min at } 100 \\
\text { r.p.m. } \\
1 \text { min at } 200 \\
\text { r.p.m. } \\
\text { Diosna mixer }\end{array}$ & - & $\begin{array}{c}\text { Dividing into } \\
300 \mathrm{~g} \text { pieces } \\
\text { Moulding by } \\
\text { hand and panning }\end{array}$ & $\begin{array}{c}50 \mathrm{~min}, 30^{\circ} \mathrm{C} \\
80 \% \mathrm{rh}\end{array}$ & $\begin{array}{c}\text { Initial steam } \\
\text { injection of } 0.5 \mathrm{~L} \text {, } \\
230^{\circ} \mathrm{C} \\
55 \mathrm{~min}, 200^{\circ} \mathrm{C}\end{array}$ & $\begin{array}{l}\text { (Döring et al., } \\
\text { 2017) }\end{array}$ \\
\hline $\begin{array}{l}\text { Wholemeal rye } \\
\text { flour }(1,000 \mathrm{~g})\end{array}$ & $\begin{array}{l}\text { Sourdough } \\
\text { fermentation } \\
\text { (water addition } \\
\text { equivalent to } \\
300 \mathrm{FU} \text { ) }\end{array}$ & $\begin{array}{l}10 \text { min spiral } \\
\text { mixer (at low } \\
\text { speed) }\end{array}$ & $10 \mathrm{~min}$ & $\begin{array}{c}\text { Dividing into } 5 \\
\text { pieces ( } 350 \mathrm{~g} \\
\text { each) } \\
\text { Moulding by } \\
\text { hand and panning }\end{array}$ & $\begin{array}{l}35^{\circ} \mathrm{C}, 75 \% \mathrm{rh} \text {, } \\
\text { until dough } \\
\text { reaches top } \\
\text { of the pan }\end{array}$ & $\begin{array}{l}10 \text { s steaming } \\
10 \mathrm{~min}, 260^{\circ} \mathrm{C} \\
30 \mathrm{~min}, 220^{\circ} \mathrm{C}\end{array}$ & $\begin{array}{l}\text { (Stępniewska } \\
\text { et al., 2019) }\end{array}$ \\
\hline
\end{tabular}




\begin{tabular}{|c|c|c|c|c|c|c|c|}
\hline Raw material & Dough type(s) & Mixing & Resting & Dividing/Shaping & Proofing & Baking & Reference \\
\hline $\begin{array}{l}\text { Wholemeal rye } \\
\text { flour }(100 \mathrm{~g})\end{array}$ & $\begin{array}{c}\text { Yeast } \\
\text { fermentation } \\
\text { (batter system) }\end{array}$ & $3 \mathrm{~min}$ & - & $\begin{array}{l}\text { Poured into } \\
\text { moulds }\end{array}$ & $12 \mathrm{~min}$ & $\begin{array}{c}65 \mathrm{~min} \\
160^{\circ} \mathrm{C} \text { (upper } \\
\text { heater) } \\
220^{\circ} \mathrm{C} \text { (lower } \\
\text { heater) }\end{array}$ & $\begin{array}{l}\text { (Torbica } \\
\text { et al., 2019) }\end{array}$ \\
\hline $\begin{array}{l}\text { Wholemeal rye } \\
\text { flour }(800 \mathrm{~g})\end{array}$ & $\begin{array}{c}\text { Sourdough } \\
\text { fermentation } \\
\text { (German standard } \\
\text { method) }\end{array}$ & $\begin{array}{c}10 \text { min, } 30^{\circ} \mathrm{C} \text { flat } \\
\text { dough stirrer } \\
\text { (Hobart N50) }\end{array}$ & $45 \mathrm{~min}$ & $\begin{array}{l}\text { Dividing into two } \\
\text { pieces }\end{array}$ & $\begin{array}{c}45 \mathrm{~min}, 32^{\circ} \mathrm{C} \\
78 \% \mathrm{rh}\end{array}$ & $\begin{array}{l}\text { Two steaming } \\
\text { (for } 1 \mathrm{~s} \text { and } 3 \mathrm{~s} \text { ) } \\
55 \mathrm{~min}, 210^{\circ} \mathrm{C}\end{array}$ & $\begin{array}{l}\text { (Oest et al., } \\
\text { 2020) }\end{array}$ \\
\hline
\end{tabular}

rh: relative humidity; FU: farinograph unit. 
assumed that the possible mechanism of complex formation might be mainly enzymatic, suggesting that peroxidase and $\mathrm{H}_{2} \mathrm{O}_{2}$ produced by the yeast cells caused enzymatic cross-linking of AX via ferulic acid residues connected to AX and AX-ferulic acid-protein via ferulic acidtyrosine (Buksa, 2016).

Among rye constituents, enzymes, especially amylases and endo-xylanases, play a significant role in bread quality. In general, rye flour with a low falling number (corresponding to high amylase activity) results in a dough-like bread with sticky crumb, while rye flour with a relatively high falling number results in a hard and dense bread (Katina et al., 2014). During fermentation, endo-xylanases hydrolyse internal $1 \rightarrow 4$ linkage between xylopyranosil residues in the AX backbone, causing a drastic reduction in molecular weight and consequently resulting in a partial solubilisation of water-unextractable AXs. The $\mathrm{pH}$ optimum of endo-xylanase is 4.5 and it is active between 3.8 and $5.3 \mathrm{pH}$ at $40{ }^{\circ} \mathrm{C}$, which corresponds well with the conditions of typical rye dough fermentation stages used in sourdough and direct rye breadmaking methods (Cyran, 2015).

Of course, rye bread properties and the functionality of flour constituents are influenced by other factors such as particle size distribution of the flour and the applied bread making method as well. Granulation significantly affects dough behaviour during fermentation. On the one hand, fermentation of dough with finer flour is more intense, which results from easier access of enzymes to starch. On the other hand, a flour with very fine granulation may have higher buffering properties, which is associated with a higher content of soluble ingredients; that poses a risk of excessive degradation of substrates responsible for creating the dough and bread structure (Stępniewska et al., 2019).

The most typical way of baking rye bread is to use sourdough method, which has several advantages against straight-dough method (Djukić et al., 2014). Sourdough originated acidity improves the baking quality of rye, which is mostly based on the swelling and degradation of cell walls, arabinoxylans, and proteins during fermentation. Acidity inhibits the activity of amylases and proteases in rye dough, preventing the excessive degradation of starch and proteins. The structure of rye starch is also changing during fermentation to enable the starch to absorb more water. Furthermore, acidic conditions increase the solubility and swelling capacity of arabinoxylans (Katina et al., 2014). Increased acidity protects also against mould growth and thus contributes to product shelf-life. Beside acids, alcohols and other volatiles forming during fermentation contribute to the aroma and taste of the bread (Deleu et al., 2020). Beside its technological benefits, sourdough fermentation has several health-promoting effects as well, such as increasing the level of bioactive compounds (Koistinen et al., 2018).

\section{NOVEL RYE PRODUCTS AND FUTURE TRENDS}

Nowadays, beside conventional breads and bakery products, several different types of food products from rye can already be found on the market (e.g. crispbreads, snacks, porridges, breakfast cereals, etc.), especially in the Nordic countries, and their number is growing continuously (Nordic Rye Forum).

Development of new rye-based products is carried out according to different aspects and objectives. As consumers became more health-conscious, the demand for healthier products of higher dietary fibre and bioactive compound contents increased as well. Therefore, more studies 
aim the development of novel fibre-rich rye milling products (Silventoinen et al., 2021) and bakery products of higher fibre (Kołodziejczyk et al., 2020) and bioactive compound (Przygodzka and Zieliński, 2016) contents. However, increased dietary fibre content usually impairs end-product quality, therefore, the improvement of technological and sensory properties of rye products are also the objectives of several $R \& D$ works. Heat treatment might be able to contribute to improve baking quality of rye flours by the modification of pasting properties (Torbica et al., 2019). Another approach is using enzymes to modify and improve bread dough rheological properties and baking quality. The proper combination of xylanase and transglutaminase seemed to be enhancing protein networking in rye dough and improving the quality of simple yeast-leavened rye bread (Döring et al., 2017). Sensory properties of high fibre rye crispbreads can be improved by particle size reduction (Alam et al., 2014) or by lactic acid fermentation (Nikinmaa et al., 2020) of the bran fraction.

Extrusion-based 3D printing technique can be applied to develop high protein and fibre snacks consisting of milk powder and wholemeal rye flour (Lille et al., 2020), which is an interesting but currently a challenging solution for developing novel rye-based products.

More and more people are affected by a kind of food intolerance nowadays, and it might be challenging for them to maintain a balanced and varied diet. In the last few years, great efforts have been made to develop gluten-free products of higher nutritional value. The possibility of developing gluten-free rye bread by degrading proteins has been investigated by Walter et al. (2015). It was found that the application of prolyl endopeptidase in sourdough system results in the degradation of gluten to concentrations below $20 \mathrm{mg} \mathrm{kg}^{-1}$, however, the loss of rye protein functionality should be replaced by gluten-free proteins or hydrocolloids. As mentioned in Section 2.3, rye products due to potentially high FODMAP content might not be suitable for patients suffering from IBS. Low-FODMAP diet, which usually coupled also with low fibre intake, however, can influence intestinal microbiota negatively (Laatikainen et al., 2019). Randomised clinical trials confirmed the suitability of low-FODMAP rye breads in the diet of IBS patients (Laatikainen et al., 2016; Pirkola et al., 2018). Therefore, the development of rye products with low FODMAP content is of great interest to researchers, to enable IBS patients to consume rye products rich in nutrients (Pejcz et al., 2020; Pitsch et al., 2021).

As it can be seen, rye, like wheat, is a versatile raw material and can be utilised in many ways. However, rye still holds many untapped opportunities.

\section{ACKNOWLEDGEMENTS}

This work was supported by the GalgaGabona project: Developments to improve the conditions of human utilization of oats and rye in terms of food safety, agrotechnology, processing technology and nutritional value (2017-1.3.1-VKE-2017-00004, NRDI Office). The work is related to the realisation of the scientific goals of the Thematic Excellence Program (BUTE Biotechnology thematic program, TKP-2-1/PALY-2020, NRDI Office) and the National Talent Programme of Ministry of Human Resources (NTP-NFTÖ-20-B-0272). This work is also related to the work from COST Action 18101 SOURDOMICS "Sourdough biotechnology network towards novel, healthier and sustainable food and bioprocesses". 


\section{REFERENCES}

Afzal, S., Shehzad, A., Randhawa, M.A., Asghar, A., Shoaib, M., and Jahangir, M.A. (2013). Health benefits and importance of utilizing wheat and rye. Pakistan Journal of Food Science, 23(4): 212-222.

Alam, S.A., Järvinen, J., Kirjoranta, S., Jouppila, K., Poutanen, K., and Sozer, N. (2014). Influence of particle size reduction on structural and mechanical properties of extruded rye bran. Food and Bioprocess Technology, 7(7): 2121-2133, https://doi.org/10.1007/s11947-013-1225-2.

Andersson, A.A.M., Dimberg, L., Åman, P., and Landberg, R. (2014). Recent findings on certain bioactive components in whole grain wheat and rye. Journal of Cereal Science, 59(3): 294-311, https://doi.org/10. 1016/j.jcs.2014.01.003.

Andersson, R., Fransson, G., Tietjen, M., and Åman, P. (2009). Content and molecular-weight distribution of dietary fiber components in whole-grain rye flour and bread. Journal of Agricultural and Food Chemistry, 57(5): 2004-2008, https://doi.org/10.1021/jf801280f.

Aprodu, I. and Banu, I. (2017). Milling, functional and thermo-mechanical properties of wheat, rye, triticale, barley and oat. Journal of Cereal Science, 77(11): 42-48, https://doi.org/10.1016/j.jcs.2017.07. 009.

Arendt, E.K. and Zannini, E. (2013). Rye. In: Cereal grains for the food and beverage industries. Woodhead Publishing, Cambridge, United Kingdom, pp. 220-243, https://doi.org/10.1533/9780857098924.220.

Arens, U. (2015). Authorised EU health claim for rye fibre. In: Sadler, M.J. (Ed.), Foods, nutrients and food ingredients with authorised EU health claims, Vol. 2. Woodhead Publishing, Cambridge, United Kingdom, pp. 129-137, https://doi.org/10.1016/B978-1-78242-382-9.00007-4.

Bağcl, A., Gecgel, Ü., Dursun, N., Özcan, M.M., Tamkoç, A., Özer, İ., and Özcan, M.M. (2019). The oil yield , mineral content, and fatty acid compositions of some rye (Secale cereale) grains. Iranian Journal of Chemistry and Chemical Engineering, 38(5): 285-292, https://doi.org/10.30492/ijcce.2019.32094.

Bánfalvi, Á., Németh, R., Bagdi, A., Gergely, S., Rakszegi, M., Bedő, Z., Láng, L., Vida, G., and Tömösközi, S. (2020). A novel approach to the characterisation of old wheat (Triticum aestivum L.) varieties by complex rheological analysis. Journal of the Science of Food and Agriculture, 100: 4409-4417, https:// doi.org/10.1002/jsfa.10479.

Banu, I., Stoenescu, G., Ionescu, V., and Aprodu, I. (2011). Estimation of the baking quality of wheat flours based on rheological parameters of the Mixolab curve. Czech Journal of Food Sciences, 29(1): 35-44.

Beck, M., Jekle, M., Selmair, P.L., Koehler, P., and Becker, T. (2011). Rheological properties and baking performance of rye dough as affected by transglutaminase. Journal of Cereal Science, 54(1): 29-36, https://doi.org/10.1016/j.jcs.2011.01.012.

Békés, F. and Wrigley, C.W. (2015). The protein chemistry of cereal grains. In: Wrigley, C., Corke, H., Seethamaran, K., and Faubion, J. (Eds.), Encyclopedia of food grains, Second Edition. Elsevier Ltd., Oxford, United Kingdom, pp. 98-108, https://doi.org/10.1016/B978-0-12-394437-5.00101-7.

Bender, D., Schmatz, M., Novalin, S., Nemeth, R., Chrysanthopoulou, F., Tömösközi, S., Török, K., Schoenlechner, R., and Amico, S.D. (2017). Chemical and rheological characterization of arabinoxylan isolates from rye bran. Chemical and Biological Technologies in Agriculture, 4(14): 1-8, https://doi.org/ 10.1186/s40538-017-0096-6.

Biel, W., Kazimierska, K., and Bashutska, U. (2020). Nutritional value of wheat, triticale, barley and oat grains. Acta Scientiarum Polonorum Zootechnica, 19(2): 19-28, https://doi.org/10.21005/asp.2020.19.2.03.

Boskov Hansen, H., Andreasen, M.F., Nielsen, M.M., Larsen, L.M., Bach Knudsen, K.E., Meyer, A.S., Christensen, L.P., and Hansen, A. (2002). Changes in dietary fibre, phenolic acids and activity of 
endogenous enzymes during rye bread-making. European Food Research and Technology, 214(1): 3342, https://doi.org/10.1007/s00217-001-0417-6.

Bucsella, B., Molnár, D., Harasztos, A.H., and Tömösközi, S. (2016). Comparison of the rheological and end-product properties of an industrial aleurone-rich wheat flour, whole grain wheat and rye flour. Journal of Cereal Science, 69: 40-48, https://doi.org/10.1016/j.jcs.2016.02.007.

Buksa, K. (2016). Application of model bread baking in the examination of arabinoxylan - protein complexes in rye bread. Carbohydrate Polymers, 148: 281-289, https://doi.org/10.1016/j.carbpol.2016.04.071.

Buksa, K., Nowotna, A., Praznik, W., Gambuś, H., Ziobro, R., and Krawontka, J. (2010). The role of pentosans and starch in baking of wholemeal rye bread. Food Research International, 43(8): 2045-2051, https://doi.org/10.1016/j.foodres.2010.06.005.

Buksa, K., Nowotna, A., and Ziobro, R. (2016). Application of cross-linked and hydrolyzed arabinoxylans in baking of model rye bread. Food Chemistry, 192: 991-996, https://doi.org/10.1016/j.foodchem.2015.07.104.

Buksa, K., Ziobro, R., Nowotna, A., and Gambuś, H. (2013). The influence of native and modified arabinoxylan preparations on baking properties of rye flour. Journal of Cereal Science, 58(1): 23-30, https://doi.org/10.1016/j.jcs.2013.04.007.

Cetiner, B., Tömösközi, S., Török, K., Salantur, A., and Koksel, H. (2020). Comparison of the arabinoxylan composition and physical properties of old and modern bread wheat (Triticum aestivum L.) and landraces genotypes. Cereal Chemistry, 97(2): 505-514, https://doi.org/10.1002/cche.10265.

Chen, C.H. and Bushuk, W. (1970). Nature of proteins in triticale and its parental species: I. Solubility characteristics and amino acid composition of endosperm proteins. Canadian Journal of Plant Science, 50(2): 9-14.

Chibbar, R.N., Jaiswal, S., Gangola, M., and Båga, M. (2016). Carbohydrate metabolism. In: Corke, H., Seethamaran, K., and Wrigley, C. (Eds.), Encyclopedia of food grains. Elsevier Ltd., Oxford, United Kingdom, pp. 1-13, Chapter 89, https://doi.org/10.1016/B978-0-12-394437-5.00089-9.

Cyran, M.R. (2015). Dietary fiber arabinoxylans in processed rye: milling- and breadmaking-induced changes. In: Preedy, V.R. (Ed.), Processing and impact on active components in food. Academic Press, pp. 319-328, https://doi.org/10.1016/B978-0-12-404699-3.00038-X.

David, I., Velciov, A., Corina, M., Bujanca, G., and Danci, M. (2019). The influence of pentosanases enzymes on rye flour. 19th International Multidisciplinary Scientific GeoConference SGEM 2019, 30 June - 6 July, 2019. Sofia, Bulgaria. pp. 985-992. https://doi.org/10.5593/sgem2019/6.1/S25.127.

Deleu, L.J., Lemmens, E., Redant, L., and Delcour, J.A. (2020). The major constituents of rye (Secale cereale L.) flour and their role in the production of rye bread, a food product to which a multitude of health aspects are ascribed. Cereal Chemistry, 97(4): 739-754, https://doi.org/10.1002/cche.10306.

Dencic, S., DePauw, R., Kobiljski, B., and Momcilovic, V. (2013). Hagberg falling number and rheological properties of wheat cultivars in wet and dry preharvest periods. Plant Production Science, 16(4): 342-351, https://doi.org/10.1626/pps.16.342.

Djukić, D.A., Radoví, M.M., Mandić, L.G., and Vesković Moraečanin, S.M. (2014). Effect of bread dough mixing method on rye bread quality. Acta Periodica Technologica, 45: 11-22, https://doi.org/10.2298/ APT1445011D.

Doehlert, D.C., Simsek, S., Thavarajah, D., Thavarajah, P., and Ohm, J.B. (2013). Detailed composition analyses of diverse oat genotype kernels grown in different environments in North Dakota. Cereal Chemistry, 90(6): 572-578, https://doi.org/10.1094/CCHEM-09-12-0111-R.

Döring, C., Hussein, M.A., Jekle, M., and Becker, T. (2017). On the assessments of arabinoxylan localization and enzymatic modifications for enhanced protein networking and its structural impact on rye dough and bread. Food Chemistry, 229: 178-187, https://doi.org/10.1016/j.foodchem.2017.02.053. 
Döring, C., Nuber, C., Stukenborg, F., Jekle, M., and Becker, T. (2015). Impact of arabinoxylan addition on protein microstructure formation in wheat and rye dough. Journal of Food Engineering, 154: 10-16, https://doi.org/10.1016/j.jfoodeng.2014.12.019.

Dubat, A. (2010). A new AACC International approved method to measure rheological properties of a dough sample. Cereal Foods World, 55(3): 150-153, https://doi.org/10.1094/CFW-55-3-0150.

EFSA Panel on Dietetic Products Nutrition and Allergies (NDA) (2014). Scientific Opinion on the substantiation of a health claim related to high-fibre sourdough rye bread and reduction of post-prandial glycaemic responses pursuant to Article 13 (5) of Regulation (EC) No 1924/2006 1. EFSA Journal, 12(10): 1-11, 3837, https://doi.org/10.2903/j.efsa.2014.3837.

FAO (2019). FAOSTAT, Available at: www.fao.org.

Fraś, A., Gołębiewska, K., Gołębiewski, D., Mańkowski, D.R., Boros, D., and Szecówka, P. (2016). Variability in the chemical composition of triticale grain, flour and bread. Journal of Cereal Science, 71: 6672, https://doi.org/10.1016/j.jcs.2016.06.016.

Frølich, W., Åman, P., and Tetens, I. (2013). Whole grain foods and health - a Scandinavian perspective. Food and Nutrition Research, 57: 1-7, https://doi.org/10.3402/fnr.v57i0.18503.

Göllner, E.M., Ichinose, H., Kaneko, S., Blaschek, W., and Classen, B. (2011). An arabinogalactan-protein from whole grain of Avena sativa L. belongs to the wattle-blossom type of arabinogalactan-proteins. Journal of Cereal Science, 53(2): 244-249, https://doi.org/10.1016/j.jcs.2011.01.004.

Gomand, S.V., Verwimp, T., Goesaert, H., and Delcour, J.A. (2011). Structural and physicochemical characterisation of rye starch. Carbohydrate Research, 346(17): 2727-2735, https://doi.org/10.1016/j. carres.2011.09.024.

Gómez, M., Pardo, J., Oliete, B., and Caballero, P.A. (2009). Effect of the milling process on quality characteristics of rye flour. Journal of the Science of Food and Agriculture, 89(3): 470-476, https://doi. org/10.1002/jsfa.3475.

Grossmann, I., Döring, C., Jekle, M., Becker, T., and Koehler, P. (2016). Compositional changes and baking performance of rye dough as affected by microbial transglutaminase and xylanase. Journal of Agricultural and Food Chemistry, 64(28): 5751-5758, https://doi.org/10.1021/acs.jafc.6b01545.

Grossmann, I. and Koehler, P. (2016). Fractionation-reconstitution studies to determine the functional properties of rye flour constituents. Journal of Cereal Science, 70: 1-8, https://doi.org/10.1016/j.jcs.2016. 05.006.

Hansen, H.B., Møller, B., Andersen, S.B., Jørgensen, J.R., and Hansen, Å. (2004). Grain characteristics, chemical composition, and functional properties, of rye (Secale cereale L.) as influenced by genotype and harvest year. Journal of Agricultural and Food Chemistry, 52(8): 2282-2291, https://doi.org/10. 1021/jf0307191.

Hulse, J.H. and Laing, E.M. (1974). Nutritive value of triticale protein (and the proteins of wheat and rye). International Development Research Centre.

Hungarian Standard (1988). Lisztvizsgálati módszerek. Sütéspróba (Flour test methods. Baking test) MSZ: $6369 / 8$.

ISO. (1985). Wheat flour and rye flour - general guidance on the drafting of bread-making tests. ISO 6820: 1985.

Ispiryan, L., Zannini, E., and Arendt, E.K. (2020). Characterization of the FODMAP-profile in cerealproduct ingredients. Journal of Cereal Science, 92: 102916, https://doi.org/10.1016/j.jcs.2020. 102916.

Janssen, F., Wouters, A.G.B., Linclau, L., Waelkens, E., Derua, R., Dehairs, J., Moldenaers, P., Vermant, J., and Delcour, J. A. (2020a). The role of lipids in determining the air-water interfacial properties of 
wheat, rye, and oat dough liquor constituents. Food Chemistry, 319(2020): 126565, https://doi.org/10. 1016/j.foodchem.2020.126565.

Janssen, F., Wouters, A.G.B., Meeus, Y., Moldenaers, P., Vermant, J., and Delcour, J.A. (2020b). The role of non-starch polysaccharides in determining the air-water interfacial properties of wheat, rye, and oat dough liquor constituents. Food Hydrocolloids, 105(2020): 105771, https://doi.org/10.1016/j.foodhyd. 2020.105771.

Jonsson, K., Andersson, R., Bach Knudsen, K.E., Hallmans, G., Hanhineva, K., Katina, K., Kolehmainen, M., Kyrø, C., Langton, M., Nordlund, E., Lærke, H.N., Olsen, A., Poutanen, K., Tjønneland, A., and Landberg, R. (2018). Rye and health - where do we stand and where do we go? Trends in Food Science and Technology, 79(6): 78-87, https://doi.org/10.1016/j.tifs.2018.06.018.

Juntunen, K.S., Niskanen, L.K., Liukkonen, K.H., Poutanen, K.S., Holst, J.J., and Mykkänen, H.M. (2002). Postprandial glucose, insulin, and incretin responses to grain products in healthy subjects. The American Journal of Clinical Nutrition, 75(2): 254-262.

Kan, A. (2015). Characterization of the fatty acid and mineral compositions of selected cereal cultivars from Turkey. Records of Natural Products, 9(1): 124-134.

Kariluoto, S., Vahteristo, L., Salovaara, H., Katina, K., Liukkonen, K.H., and Piironen, V. (2004). Effect of baking method and fermentation on folate content of rye and wheat breads. Cereal Chemistry, 81(1): 134-139, https://doi.org/10.1094/CCHEM.2004.81.1.134.

Karppinen, S., Myllymäki, O., Forssell, P., and Poutanen, K. (2003). Fructan content of rye and rye products. Cereal Chemistry, 80(2): 168-171.

Katina, K., Hartikainen, K., and Poutanen, K. (2014). Process-induced changes in rye foods-rye baking. In: Poutanen, K., and Åman, P. (Eds.), Rye and health, 1st ed., Elsevier Ltd., Oxford, United Kingdom, pp. 7-21, https://doi.org/10.1016/B978-1-891127-81-6.50002-X.

Klassen, A.J. and Hill, R.D. (1971). Comparison of starch from Triticale and its parental species. Cereal Chemistry, 48: 647-654.

Knudsen, K.E.B. (2014). Fiber and nonstarch polysaccharide content and variation in common crops used in broiler diets. Poultry Science, 93(9): 2380-2393, https://doi.org/10.3382/ps.2014-03902.

Knudsen, K.E.B. and Lærke, H.N. (2010). Rye arabinoxylans: molecular structure, physicochemical properties. Cereal Chemistry, 87(4): 353-362.

Koistinen, V.M., Mattila, O., Katina, K., Poutanen, K., Aura, A. M., and Hanhineva, K. (2018). Metabolic profiling of sourdough fermented wheat and rye bread. Scientific Reports, 8(1): 1-11, 5684, https://doi. org/10.1038/s41598-018-24149-w.

Kołodziejczyk, P., Michniewicz, J., Buchowski, M.S., and Paschke, H. (2020). Effects of fibre-rich rye milling fraction on the functional properties and nutritional quality of wholemeal rye bread. Journal of Food Science and Technology, 57(1): 222-232, https://doi.org/10.1007/s13197-019-04050-8.

Kučerová, J. (2009). Effects of location and year on technological quality and pentosan content in rye. Czech Journal of Food Sciences, 27(6): 418-424, https://doi.org/10.17221/8/2009-cjfs.

Kulichová, K., Sokol, J., Nemeček, P., Maliarová, M., Maliar, T., Havrlentová, M., and Kraic, J. (2019). Phenolic compounds and biological activities of rye (Secale cereale L .) grains. Open Chemistry, 17(1): 988-999.

Kunkulberga, D., Linina, A., Kronberga, A., Kokare, A., and Lenenkova, I. (2017). Grain quality of winter rye cultivars grown in Latvia. FOODBALT 2017, 1: 121-125, https://doi.org/10.22616/foodbalt.2017. 015.

Laatikainen, R., Koskenpato, J., Hongisto, S.M., Loponen, J., Poussa, T., Hillilä, M., and Korpela, R. (2016). Randomised clinical trial: low-FODMAP rye bread vs. regular rye bread to relieve the symptoms of 
irritable bowel syndrome. Alimentary Pharmacology \& Therapeutics, 44(5): 460-470, https://doi.org/10. 1111/apt.13726.

Laatikainen, R., Jalanka, J., Loponen, J., Hongisto, S., Hillilä, M., and Koskenpato, J. (2019). Randomised clinical trial: effect of low- FODMAP rye bread versus regular rye bread on the intestinal microbiota of irritable bowel syndrome patients: association with individual symptom variation. BMC Nutrition, 5: 12, https://doi.org/10.1186/s40795-019-0278-7.

Laidig, F., Piepho, H.P., Rentel, D., Drobek, T., Meyer, U., and Huesken, A. (2017). Breeding progress, variation, and correlation of grain and quality traits in winter rye hybrid and population varieties and national on-farm progress in Germany over 26 years. Theoretical and Applied Genetics, 130(5): 981-998, https://doi.org/10.1007/s00122-017-2865-9.

Langó, B., Bóna, L., Ács, E., and Tömösközi, S. (2017). Nutritional features of triticale as affected by genotype, crop year, and location. Acta Alimentaria, 46: 238-245, https://doi.org/10.1556/066.2017.46. 2.14 .

Langó, B., Bóna, L., Ng, P.K.W., Ács, E., Török, K., and Tömösközi, S. (2018). Evaluation of carbohydrate properties and end-use quality of hexaploid triticale and its relationship to solvent retention capacity. Journal of Cereal Science, 84(10): 95-102, https://doi.org/10.1016/j.jcs.2018.10.005.

Leinonen, K.S., Poutanen, K.S., and Mykkanen, H.M. (2000). Rye bread decreases serum total and LDL cholesterol in men with moderately elevated serum cholesterol. The Journal of Nutrition, 130(2): 164170, https://doi.org/10.1093/jn/130.2.164.

Lille, M., Kortekangas, A., Heiniö, R.L., and Sozer, N. (2020). Structural and textural characteristics of 3Dprinted protein- and dietary fibre-rich snacks made of milk powder and wholegrain rye flour. Foods, 9(11): 1527, https://doi.org/10.3390/foods9111527.

Lindhauer, M. G. (2014). Standard methods and criteria to predict bread cereal quality - do they still meet the demands of modern raw materials and their processing? FOODBALT, 2014: 336-338.

Liu, J., Yu, L.L., and Wu, Y. (2020). Bioactive components and health beneficial properties of whole wheat foods. Journal of Agricultural and Food Chemistry, 68(46): 12904-12915, https://doi.org/10.1021/acs. jafc.0c00705.

Malalgoda, M. and Simsek, S. (2017). Celiac disease and cereal proteins. Food Hydrocolloids, 68: 108-113, https://doi.org/10.1016/j.foodhyd.2016.09.024.

Meeus, Y., Janssen, F., Wouters, A.G.B., Delcour, J.A., and Moldenaers, P. (2020). Linear and non-linear rheology of bread doughs made from blends of wheat (Triticum aestivum L.) and rye (Secale cereale L.) flour. Food and Bioprocess Technology 13(1): 159-171, https://doi.org/10.1007/s11947-01902393-w.

Meißner, M. and AGF, Arbeitsgemeinschaft Getreideforschung (Eds.), (2016). Standard-Methoden für Getreide, Mehl und Brot mit allen aktuellen ICC-Standards. Detmold 8. überarbeitete und erweiterte Auflage 2016. Verlag Moritz Schäfer, pp. 841.

Mhd Omar, N.A., Wu, H., and Larsson, A. (2020). Long-term whole-grain rye and wheat consumption and their associations with selected biomarkers of inflammation, endothelial function, and cardiovascular disease. European Journal of Clinical Nutrition, 75(1): 123-132, https://doi.org/10.1038/s41430-02000714-3.

Michela, P. and Lorenz, K. (1976). The vitamins of triticale, wheat, and rye. Cereal Chemistry, 53(6): 853-861.

Mihhalevski, A., Heinmaa, I., Traksmaa, R., Pehk, T., Mere, A., and Paalme, T. (2012). Structural changes of starch during baking and staling of rye bread. Journal of Agricultural and Food Chemistry, 60(34): 8492-8500, https://doi.org/10.1021/jf3021877. 
Munteanu, M., Voicu, G., Stefan, E.M., Constantin, G.A., Popa, L., and Mihailov, N. (2015). Farinograph characteristics of wheat flour dough and rye flour dough. International Symposium ISB-INMA TEH 2015, 29-31 October 2015. Bucharest, Romania pp. 645-650.

Nikinmaa, M., Kajala, I., Liu, X., Nordlund, E., and Sozer, N. (2020). The role of rye bran acidification and in situ dextran formation on structure and texture of high fibre extrudates. Food Research International, 137(4): 109438, https://doi.org/10.1016/j.foodres.2020.109438.

Nordic Rye Forum (n.d.). Rye foods, Available at: https://www.nordicryeforum.info/rye-foods.

Nyström, L., Lampi, A.-M., Andersson, A.A.M., Kamal-Eldin, A., Gebruers, K., Courtin, C. M., Delcour, J.A., Li, L., Ward, J.L., Fraś, A., Boros, D., Rakszegi, M., Bedo, Z., Shewry, P.R., and Piironen, V. (2008). Phytochemicals and dietary fiber components in rye varieties in the HEALTHGRAIN Diversity Screen. Journal of Agricultural and Food Chemistry, 56(21): 9758-9766, https://doi.org/10.1021/ jf801065r.

Oest, M., Bindrich, U., Voß, A., Kaiser, H., and Rohn, S. (2020). Rye bread defects: analysis of composition and further influence factors as determinants of dry-baking. Foods, 9(12): 1900, https://doi.org/10.3390/ foods9121900.

Pejcz, E., Spychaj, R., and Gil, Z. (2020). Technological methods for reducing the content of fructan in rye bread. European Food Research and Technology, 246(9): 1839-1846, https://doi.org/10.1007/s00217020-03537-5.

Pihlava, J. M., Hellström, J., Kurtelius, T., and Mattila, P. (2018). Flavonoids, anthocyanins, phenolamides, benzoxazinoids, lignans and alkylresorcinols in rye (Secale cereale) and some rye products. Journal of Cereal Science, 79: 183-192, https://doi.org/10.1016/j.jcs.2017.09.009.

Piironen, V. and Lampi, A.M. (2014). Rye as a source of phytosterols, tocopherols, and tocotrienols. In: Poutanen, K., and Åman, P. (Eds.), Rye and health, 1st ed. Elsevier Ltd., Oxford, United Kingdom, https://doi.org/10.1016/B978-1-891127-81-6.50009-2.

Pirkola, L., Laatikainen, R., Loponen, J., Hongisto, S.M., Hillilä, M., Nuora, A., Yang, B., Linderborg, K.M., and Freese, R. (2018). Low-FODMAP vs regular rye bread in irritable bowel syndrome: randomized SmartPill ${ }^{\circledR}$ study. World Journal of Gastroenterology, 24(11): 1259-1268, https://doi.org/10.3748/wjg. v24.i11.1259.

Pitsch, J., Sandner, G., Huemer, J., Huemer, M., Huemer, S., and Weghuber, J. (2021). Quantitative assessment and content reduction through fermentation. Foods, 10(4): 894.

Pojić, M., Hadnadev, M., and Hadnadev, T.D. (2013). Gelatinization properties of wheat flour as determined by empirical and fundamental rheometric method. European Food Research and Technology, 237(3): 299-307, https://doi.org/10.1007/s00217-013-1991-0.

Ponomareva, M., Ponomarev, S., Mannapova, G., Gilmullina, L., Fomin, S., Ilalova, L., Vafina, G., and Kirillova, E. (2018). Testing methods for describing rye whole meal quality. Research Journal of Pharmaceutical, Biological and Chemical Sciences, 9(5): 2403-2413.

Poutanen, K., Katina, K., and Heiniö, R.-L. (2014). Rye. In: Zhou, W., Hui, Y.H., De Leyn, I., Pagani, M.A., Rosell, C.M., Selman, J.D., and Therdthai, N. (Eds.), Bakery products science and technology. John Wiley \& Sons, Ltd., pp. 75-87, https://doi.org/10.1002/9781118792001.ch4.

Przygodzka, M. and Zieliński, H. (2016). Characterization of the quality of novel rye-buckwheat ginger cakes by chemical markers and antioxidant capacity. Chemical Papers, 70(3): 333-342, https://doi.org/ 10.1515/chempap-2015-0217.

Ragaee, S. and Abdel-Aal, E.S.M. (2006). Pasting properties of starch and protein in selected cereals and quality of their food products. Food Chemistry, 95(1): 9-18, https://doi.org/10.1016/j.foodchem.2004.12. 012. 
Rakha, A., Åman, P., and Andersson, R. (2011). Dietary fiber in triticale grain: variation in content, composition, and molecular weight distribution of extractable components. Journal of Cereal Science, 54(3): 324-331, https://doi.org/10.1016/j.jcs.2011.06.010.

Redant, L., Buggenhout, J., Brijs, K., and Delcour, J.A. (2017). Extractability and chromatographic separation of rye (Secale cereale L.) flour proteins. Journal of Cereal Science, 73: 68-75, https://doi.org/10. 1016/j.jcs.2016.11.010.

Saeed, F., Pasha, I., Anjum, F.M., and Sultan, M.T. (2011). Arabinoxylans and arabinogalactans: a comprehensive treatise. Critical Reviews in Food Science and Nutrition, 51(5): 467-476, https://doi.org/ 10.1080/10408391003681418.

Saied Hussein, A.M., Ali, H.S., and Al-Khalifa, A.R. (2018). Quality assessment of some spring bread wheat cultivars. Asian Journal of Crop Science, 10(1): 10-21, https://doi.org/10.3923/ajcs.2018. 10.21 .

Salmenkallio-Marttila, M. and Hovinen, S. (2005). Enzyme activities, dietary fibre components and rheological properties of wholemeal flours from rye cultivars grown in Finland. Journal of the Science of Food and Agriculture, 85(8): 1350-1356, https://doi.org/10.1002/jsfa.2128.

Sapirstein, H.D. and Bushuk, W. (2016). Rye grain: its genetics, production, and utilization. In: Corke, H., Seethamaran, K., and Wrigley, C. (Eds.), Encyclopedia of food grains. Academic Press, pp. 159-167, https://doi.org/10.1016/B978-0-08-100596-5.00017-2.

Shewry, P.R., Hawkesford, M.J., Piironen, V., Lampi, A.M., Gebruers, K., Boros, D., Andersson, A.A.M., Åman, P., Rakszegi, M., Bedo, Z., and Ward, J.L. (2013). Natural variation in grain composition of wheat and related cereals. Journal of Agricultural and Food Chemistry, 61(35): 8295-8303, https://doi. org/10.1021/jf3054092.

Shewry, P.R., Piironen, V., Lampi, A.M., Nyström, L., Li, L., Rakszegi, M., Fraś, A., Boros, D., Gebruers, K., Courtin, C.M., Delcour, J.A., Andersson, A.A.M., Dimberg, L., Bedo, Z., and Ward, J.L. (2008). Phytochemical and fiber components in oat varieties in the healthgrain diversity screen. Journal of Agricultural and Food Chemistry, 56(21): 9777-9784, https://doi.org/10.1021/jf801880d.

Silventoinen, P., Kortekangas, A., Ercili-Cura, D., and Nordlund, E. (2021). Impact of ultra-fine milling and air classification on biochemical and techno-functional characteristics of wheat and rye bran. Food Research International, 139: 109971, https://doi.org/10.1016/j.foodres.2020.109971.

Sluková, M., Jurkaninová, L., Švec, I., and Skrrivan, P. (2021). Rye - the nutritional and technological evaluation in Czech cereal technology - a review: grain and flours. Czech Journal of Food Sciences, 39(1): 3-8, https://doi.org/10.17221/203/2020-cjfs.

Stępniewska, S., Hassoon, W.H., Szafrańska, A., Cacak-Pietrzak, G., and Dziki, D. (2019). Procedures for breadmaking quality assessment of rye wholemeal flour. Foods, 8(8): 331, https://doi.org/10.3390/ foods8080331.

Stępniewska, S., Słowik, E., Cacak-Pietrzak, G., Romankiewicz, D., Szafrańska, A., and Dziki, D. (2018). Prediction of rye flour baking quality based on parameters of swelling curve. European Food Research and Technology, 244(6): 989-997, https://doi.org/10.1007/s00217-017-3014-z.

Stoddard, F.L. (1999). Survey of starch particle-size distribution in wheat and related species. Cereal Chemistry, 76(1): 145-149, https://doi.org/10.1094/CCHEM.1999.76.1.145.

Tömösközi, S. and Békés, F. (2016). Bread: dough mixing and testing operations. In: Caballero, B., Finglas, P.M., and Toldrá, F. (Eds.), Encyclopedia of food and health. Elsevier Ltd., Oxford, United Kingdom, pp. 490-499, https://doi.org/10.1016/B978-0-12-384947-2.00086-6.

Torbica, A., Belović, M., and Tomić, J. (2019). Novel breads of non-wheat flours. Food Chemistry, 282(1): 134-140, https://doi.org/10.1016/j.foodchem.2018.12.113. 
Verwimp, T., Vandeputte, G.E., Marrant, K., and Delcour, J.A. (2004). Isolation and characterisation of rye starch. Journal of Cereal Science, 39(1): 85-90, https://doi.org/10.1016/S0733-5210(03)00068-7.

Walter, T., Wieser, H., and Koehler, P. (2015). Degradation of gluten in rye sourdough products by means of a proline-specific peptidase. European Food Research and Technology, 240(3): 517-524, https://doi. org/10.1007/s00217-014-2350-5.

Warechowska, M., Warechowski, J., Tyburski, J., Siemianowska, E., Nawrocka, A., Miś, A., and SkrajdaBrdak, M. (2019). Evaluation of physicochemical properties, antioxidant potential and baking quality of grain and flour of primitive rye (Secale cereale var. Multicaule). Journal of Food Science and Technology, 56(7): 3422-3430, https://doi.org/10.1007/s13197-019-03827-1.

Welch, R.W. (2011). Nutrient composition and nutritional quality of oats and comparisons with other cereals. In: Webster, F.H., and Wood, P.J. (Eds.), Oats: chemistry and technology. Guelph Food Research Centre, Guelph, Ontario, Canada, pp. 95-108.

Wrigley, C. and Bushuk, W. (2017). Rye: grain-quality characteristics and management of quality requirements. In: Wrigley, C., Batey, I.L., and Miskelly, M. (Eds.), Cereal grains. Woodhead Publishing, Cambridge, United Kingdom, pp. 153-178, https://doi.org/10.1016/B978-0-08-100719-8.00007-3.

Yuan, T.Z., Liu, S., Reimer, M., Isaak, C., and Ai, Y. (2021). Evaluation of pasting and gelling properties of commercial flours under high heating temperatures using Rapid Visco Analyzer 4800. Food Chemistry, 344: 128616, https://doi.org/10.1016/j.foodchem.2020.128616.

Zhu, F. (2018). Triticale: nutritional composition and food uses. Food Chemistry, 241: 468-479, https://doi. org/10.1016/j.foodchem.2017.09.009.

Open Access. This is an open-access article distributed under the terms of the Creative Commons Attribution-NonCommercial 4.0 International License (https://creativecommons.org/licenses/by-nc/4.0/), which permits unrestricted use, distribution, and reproduction in any medium for non-commercial purposes, provided the original author and source are credited, a link to the CC License is provided, and changes - if any - are indicated. 